\title{
ОЦІНКА ЕФЕКТИВНОСТІ ВИКОРИСТАННЯ ТЕПЛОВОГО ПОТЕНЦІАЛУ ДОВКІЛЛЯ ТА ВЕРХНІХ ШАРІВ ЗЕМЛІ УКРАЇНИ
}

\author{
Ю.П. Морозов ${ }^{1}$, докт. техн. наук, Д.М. Чалаєв ${ }^{1,2}$, канд. техн. наук, Н.В. Ніколаєвська ${ }^{1}$, М.П. Добровольський ${ }^{2}$ \\ ${ }^{1}$ Інститут відновлюваної енергетики НАН України, \\ 02094, вул. Гната Хоткевича, 20А, м. Київ, Україна. \\ ${ }^{2}$ Інститут технічної теплофізики НАН України, \\ 03057, вул. Марії Капніст, 2а, м. Київ, Україна.
}

Проведено оиінку ефективності комбінованого використання низькопотенційної теплоти грунту та атмосферного повітря для роботи установки теплонасосного теплопостачання. Проведено аналіз основних положень нормативних документів СС та законодавчих актів Украӥни в частині віднесення теплових насосів до обладнання, яке використовує відновлювані джерела енергії та вибору критерію такого віднесення. Розглянуто мінімально допустиме значення середнього розрахункового сезонного коефічієнту корисної дії. Проаналізовано вплив тривалості температур повітря різних градацій на теплопродуктивність теплового насосу та визначено часові інтервали ефективної роботи кожного з низькопотениійних джерел. Для підвищення ефективності роботи двоконтурної теплонасосної системи запропоновано схему вилучення низькопотенційної теплоти з використанням трунтової теплової труби і повітряного теплообмінника на базі двофазного гравітаційного термосифону. Розглянуто вихідні дані та припущення для оцінки теплового потенціалу верхніх шарів Землі, який може використовуватись для геотермального теплопостачання з застосуванням теплових насосів. Виконано порівняння енергетичних характеристик геотермального і повітряного теплового насосу при їх автономної $і$ комбінованої роботи протягом року в кліматичних умовах міста Києва і показано, щзо комбіноване використання низькопотенційної теплоти атмосферного повітря і трунту дозволяе в 1,2 рази збільшити річну теплопродуктивність теплонасосної системи. На підставі проведених досліджень встановлено, щчо перевагою повітря, як теплоносія, є те, що повітряні теплові насоси можуть працювати практично повсюди $і$ не вимагають облаштування низькотемпературного контуру. Перспективним способом підвищення ефективності теплового насоса при річному ичиклі його роботи є комбіноване використання низькопотенційної теплоти трунту та повітря. Теплонасосна система з двома джерелами енергї забезпечує високу теплопродуктивність теплового насоса протягом всього року і має більш високий показник енергетичної ефективності у порівнянні з традиційними ріменнями. Бібл.11, табл.2, рис.4.

Ключові слова: енергетичний потенціал повітря, верхні шари землі, теплові насоси, енергетична ефективність.

\section{EVALUATION OF THE EFFICIENCY OF USING THE THERMAL POTENTIAL OF THE ENVIRONMENT AND THE TOP LAYERS OF THE LAND OF UKRAINE}

\author{
Y. Morozov ${ }^{1}$, doctor of technical sciences, D. Chalaev ${ }^{\mathbf{1}, \mathbf{2}}$, candidate of technical sciences, N. Nikolaievska ${ }^{\mathbf{1}}$, M. Dobrovolskyi $^{\mathbf{2}}$ \\ ${ }^{1}$ Institute of Renewable Energy of the National Academy of Sciences of Ukraine, \\ 02094, 20A, Hnata Hotkevycha St., Kyiv, Ukraine. \\ ${ }^{2}$ Institute of Engineering Thermophysics of the National Academy of Sciences of Ukraine, \\ 03057, 2a, Maria Kapnist, St., Kyiv, Ukraine.
}

An assessment of the effectiveness of the combined use of low-potential soil heat and atmospheric air for the operation of a heat pump heat supply unit has been carried out. The analysis of the main provisions of the EU regulatory documents and legislative acts of Ukraine in terms of attributing heat pumps to equipment that uses renewable energy sources and choosing the criterion for such attribution. The minimum permissible value of the average calculated seasonal efficiency is considered. The influence of the duration of air temperatures of various gradations on the heat pump heat output is analyzed and the time intervals for the effective operation of each of the lowpotential sources are determined. To increase the efficiency of the two-circuit heat pump system, a scheme for extracting low-potential heat using a soil heat pipe and an air heat exchanger based on a two-phase gravitational thermosyphon is proposed. The initial data and assumptions for assessing the thermal potential of the upper layers of the Earth, which can be used for geothermal heat supply using heat pumps, are considered. The comparison of the energy characteristics of the geothermal and air heat pump during their autonomous and combined operation throughout the year in the climatic conditions of Kiev is carried out and it is shown that the combined use of lowpotential heat of atmospheric air and soil allows to increase the annual heat output of the heat pump system by 1.2 times. Based on the studies carried out, it has been established that the advantage of air as a heat carrier is that air heat pumps can operate almost everywhere and do not require a low-temperature circuit. A promising way to increase the efficiency of a heat pump with an annual cycle of its operation is the combined use of low-potential heat of soil and air. The heat pump system with two energy sources provides high heat pump performance throughout the year and has a higher energy efficiency than traditional solutions. Bibl.11, tab.2, fig.4.

Keywords: air energy potential, upper layers of the earth, heat pumps, energy efficiency.

(C) Ю.П. Морозов, Д.М. Чалаєв, Н.В. Ніколаєвська, М.П. Добровольський, 2020

Відновлювана енергетика. 2020. № 4 


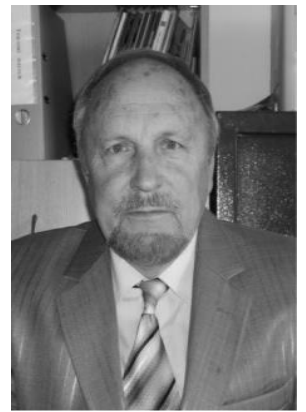

Ю.П. Морозов Yu. Morozov

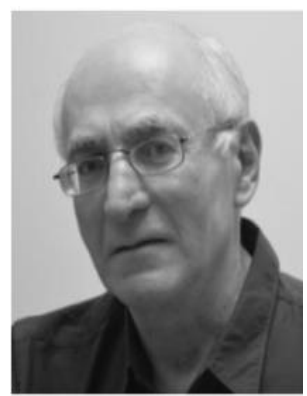

Д.М. Чалаєв D. Chalaev

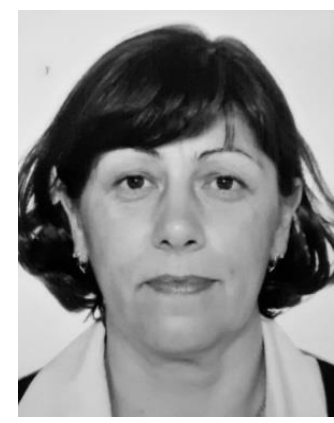

Н.В. Ніколаєвська N. Nikolaievska

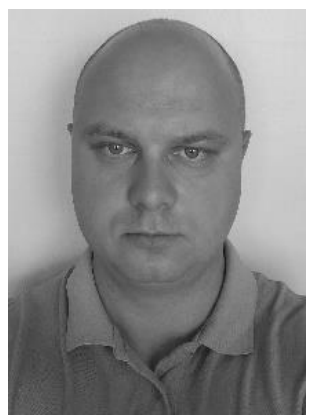

Відомості про автора: аспірант Інституту технічної теплофізики НАН України.

Освіта: Київський національний університет будівництва та архітектури.

Наукова сфера: відновлювана енергетика, використання тепла довкілля, теплоенергетика.

Публікації: 3.

ORCID: 0000-0001-9140-5158

Контакти: тел./факс: +38(066)950-27-56

e-mail: Dobrik316@gmail.com
Author information: Head of the Department of Geothermal Energy of the Institute of Renewable Energy of the National Academy of Sciences of Ukraine, doctor of technical sciences, senior researcher.

Education: National Technical University of Ukraine "Igor Sikorsky Kyiv Polytechnic Institute".

Research area: renewable energy, geothermal energy, use of warm environment.

Publications: more than 160.

ORCID: 0000-0003-1632-9735

Contacts: tel./fax: +38(044)206-28-09

e-mail: geotherm@ukr.net

Author information: Senior Researcher of the Department of Geothermal Energy of the Institute of Renewable Energy of NAS of Ukraine, Ph.D. (engineering). Leading

Researcher of the Department of Heat and Mass Transfer in Disperse Systems of the Institute of Engineering Thermophysics of NAS of Ukraine. Education: Moscow Technological Institute of Meat and Dairy Industry.

Research area: renewable energy sources, heat pumps, energy saving.

Publications: more than 100.

ORCID: 0000-0002-5154-4257

Contacts: tel.: +38 (044) 209-07-68

e-mail: chalaev@i.ua

Author information: junior researcher of the department Institute of Renewable Energy of National Academy of Sciences of Ukraine.

Education: Vladimir Polytechnic Institute.

Research area: renewable energy; geothermal energy; use of warm environment.

Publications: more than 20.

ORCID: 0000-0002-9997-4627

Contacts: tel./fax: +38(044)206-28-09

e-mail: geotherm@ukr.net

Author information: postgraduate student of the Institute of Engineering Thermophysics of NAS of Ukraine.

Education: Kyiv National University of

Construction and Architecture.

Research area: renewable energy, use of warm environment, heat power engineering.

Publications: 3 .

ORCID: 0000-0001-9140-5158

Contacts: tel./fax: $+38(066) 950-27-65$

e-mail: Dobrik316@gmail.com

М.П. Добровольський M. Dobrovolskyi 
Перелік використаних позначень та скорочень:

ЄС - Свропейський союз;

ККД - коефіцієнт корисної дії;

$\eta \quad$ - коефіцієнт корисної дії енергетичної системи з виробництва електричної енергії;

$\mathrm{SPF}_{0}$ - мінімально допустиме значення середнього розрахункового сезонного коефіцієнту корисної дії;

V - середня швидкість вітру, м/с;

Вступ. До природних джерел теплоти довкілля належать атмосферне повітря, води річок, озер, морів, верхній шар грунту та грунтові води. Також можна умовно віднести поверхневі стічні води. Згідно 3 директивою 2009/28/ЄC геотермальною $\epsilon$ енергія, яка була накопичена у вигляді теплової енергії під твердим шаром земної поверхні.

Тепловий потенціал річок, озер та морів нами не розглядається, тому що водонаповненість річок і озер суттєво залежить від господарської діяльності людини і має невизначений характер. Основні положення нормативних документів $\mathrm{CC}$, що стосуються теплових насосів, знайшли відображення в законодавчих актах України, зокрема в Законі України від 01.11.2016 № 1711VII «Про внесення змін в Закон України «Про альтернативні джерела енергії в частині віднесення теплових насосів до обладнання, яке використовує відновлювані джерела енергії». Основні зміни внесені до статті 10 Закону України « Про альтеративні джерела енергії». Нова редакція статті 10 містить загальні умови віднесення теплових насосів до обладнання відновлювальної енергетики: «Отриману за допомогою теплових насосів аеротермальну, геотермальну та гідротермальну енергію слід вважати отриманою 3 відновлювальних джерел за умови, що кінцевий вихід енергії значно перевищує споживання первинної енергії, яка необхідна для приводу теплових насосів» [1]. Геотермальна енергія або теплота Землі поділяється на повсюднорозповсюджені та геотермальні родовища [2].

Поширені геотермальні ресурси - це верхні шари Землі. Їх можна використовувати в якості джерела теплової енергії шляхом застосування теплових насосів, які набувають поширення в Україні, стаючи звичним видом теплоджерел для систем теплопостачання. Аналіз даних імпорту теплових насосів усіх типів в Україну за 2001-2015 pр. дозволяє орієнтовно оцінити їхню $\mathrm{k}$ - середнє зняття теплоти с $1 \mathrm{~m}^{3}$ повітря, кДж/ $\mathrm{M}^{3}$;

S - загальна площа житлового мікрорайону, ${ }^{2}$;

H - середня висота житлових будинків, м;

P - частка площі, яка зайнята під житлові будівлі;

СОР - коефіцієнт перетворення теплового насосу.

накопичену теплову потужність рівнем 1500 МВт [3].

Мета та завдання. Основним завданням статті $\epsilon$ порівняння ефективності використання різних типів теплових насосів, які використовують теплову енергію верхніх шарів Землі та атмосферне повітря.

Результати досліджень. Геотермальна енергія верхніх шарів Землі та теплова енергія повітря використовується для опалення приміщень за допомогою теплових насосів. В зв'язку зі згаданою директивою ЄС верхні шари грунту та грунтові води належать до геотермальних ресурсів в рамках енергії довкілля. Для підвищення ефективності роботи двоконтурної теплонасосної системи запропоновано схему вилучення низькопотенційної теплоти 3 використанням грунтової теплової труби і повітряного теплообмінника на базі двофазного гравітаційного термосифону. Критерієм віднесення теплового насосу до установок відновлюваної енергетики Директивою [1] встановлюється мінімально допустиме значення середнього розрахункового сезонного коефіцієнту корисної дії (ККД) зазначених теплових насосів $\left(\mathrm{SPF}_{0}\right)$, який дорівнює:

$$
\mathrm{SPF}_{0}=1,15 / \eta
$$

де $\eta$ - коефіцієнт корисної дії енергетичної системи 3 виробництва електричної енергії, що означає співвідношення між загальним сукупним виробництвом електроенергії та первинним споживачем енергії для виробництва електроенергї та розраховується за даними енергетичного балансу 28 країн - членів СС за 2010 р., що базується на даних Євростату (додаток VII).

Розрахункове значення ККД енергосистем ЄС станом на 2010 рік становило 45,9\%, що відповідає значенню $\mathrm{SPF}_{0}$ для теплових насосів 3 
електричним приводом на рівні 2,5. Розрахунки електричного ККД енергетичної системи України за методикою Eurostat, які наведено в [4], та відповідно до даних енергетичного балансу України за 2010 рік, опублікованого Державною службою статистики України [4], дають значення $\mathrm{SPF}_{0}$ на рівні 3,2 .
Статистичні дані Європейської асоціації теплових насосів (European Heat Pump Association, EHPA) показують, що середньорічні значення SPF і річна тривалість роботи різних типів теплових насосів змінюються в залежності від кліматичної зони, в якій експлуатується обладнання [5]. Величини цих параметрів для регіонів з холодним, середнім і теплим кліматом наведені в таблиці 1.

Таблиця 1. Середньорічні значення SPF і середньорічна тривалість використання теплових насосів в різних кліматичних зонах.

Table 1. Average annual SPF values and average annual duration of use of heat pumps in different climatic zones.

\begin{tabular}{|l|l|c|c|c|}
\hline \multirow{2}{*}{$\begin{array}{l}\text { Тип теплового } \\
\text { насоса }\end{array}$} & \multicolumn{3}{|c|}{ Кліматична зона } \\
\cline { 2 - 4 } & & холодна & середня & тепла \\
\hline \multirow{2}{*}{ повітря-вода } & Величина SPF & 2,5 & 2,6 & 2,7 \\
\cline { 2 - 5 } & Час роботи за рік, годин & 1710 & 1640 & 1170 \\
\hline $\begin{array}{l}\text { вода-вода } \\
\text { (грунт-вода) }\end{array}$ & Величина SPF & 3,5 & 3,5 & 3,5 \\
\cline { 2 - 5 } & Час роботи за рік, годин & 2470 & 2070 & 1340 \\
\hline
\end{tabular}

Тепловий потенціал повітря. На теперішний час серед теплових насосів 3 різними джерелами низькопотенційного тепла найбільш широко використовуються установки типу «повітря-вода» і «повітря-повітря». Це пояснюється тим, що повітряні теплові насоси не вимагають облаштування зовнішнього низькотемпературного контуру i можуть працювати практично всюди. Однак, через значні коливання температури зовнішнього повітря протягом року, ці системи характеризуються змінними енергетичними характеристиками, які мають тенденцію до зниження в найхолодніші періоди, коли потреба в теплі максимальна. Крім того, енергетична ефективність повітряних теплових насосів при мінусовій температурі атмосферного повітря знижується також через втрати енергії на періодичне розморожування випарника.

Для вилучення із атмосферного повітря 1 кВт·год теплоти необхідно прокачати через випарник теплового насоса близько $1000 \mathrm{~m}^{3}$ повітря. 3 урахуванням цього, тепловий потенціал повітряного басейну міського житлового мікрорайону з високою щільністю забудови можна оцінити приблизною величиною:

$$
Q=k \cdot V \cdot H \cdot \sqrt{S \cdot(1-P)},
$$

де $\mathrm{k}$ - середнє зняття теплоти с $1 \mathrm{~m}^{3}$ повітря, кДж/ $\mathrm{M}^{3} ; \mathrm{S}$ - загальна площа житлового мікрорайону, м²; Н - середня висота житлових будинків, м; P - частка площі, яка зайнята під житлові будівлі, V - середня швидкість вітру, м/с.

$\mathrm{y}$ зимовий час енергетично більш ефективні геотермальні теплонасосні системи «грунт-вода» $\mathrm{i}$ «вода-вода», які працюють 3 використанням низькопотенційної теплоти грунту (або підземних грунтових вод ) i мають високий коефіцієнт перетворення СОР, який не залежить від пори року. Незважаючи на те, що такі теплонасосні системи мають кращі енергетичні характеристики, ïx використання обмежено, що пов'язано 3 високою вартістю робіт, яке обумовлено облаштуванням поля вертикальних бурових свердловин (або горизонтальних грунтових теплообмінників).

Слід зауважити, що грунт $\epsilon$ кращим джерелом низькопотенційної теплоти тільки протягом тієї частини опалювального періоду, коли температура грунту перевищує температуру атмосферного повітря. В інші пори року енергетично більш ефективним $\epsilon$ використання теплоти атмосферного повітря. Аналізуючи коливання температури атмосферного повітря протягом року, можна виділити періоди часу, коли при цілорічному циклі роботи теплового насоса (опалення взимку і гаряче водопостачання влітку), 
система «повітря-вода» більш ефективна, ніж «грунт-вода». Таке комбіноване використання двох джерел низькопотенційної теплоти дозволить значно поліпшити показники середньорічної ефективності роботи теплового насоса.

\section{Системи}

теплонасосного теплопостачання. Багатьма авторами вже були досліджені теплонасосні системи 3 двома джерелами низькопотенційної теплоти $[6,7]$. У цих роботах система збору низькопотенційної теплоти складається 3 повітряного теплообмінника типу «Dry cooler» i грунтового теплообмінника, які через контур проміжного теплоносія підключені паралельно до випарника теплового насоса. Електрокерований триходовий клапан перемикає потік теплоносія або на повітряний, або на грунтовий теплообмінник. $\mathrm{B}$ роботі [6] зазначається, що комбіноване використання теплоти грунту та атмосферного повітря знижує теплове навантаження на грунтовий масив, що дозволяе зменшити розміри грунтового теплообмінника i зберегти більш високу температуру грунту протягом опалювального сезону. Як наслідок, вдається отримати більш високе значення коефіцієнту трансформації i заощадити близько $13 \%$ електричної енергії на привод теплового насоса.

Для підвищення ефективності роботи двоконтурної теплонасосної системи нами розроблено схему видобування низькопотенційної теплоти 3 використанням грунтової теплової труби і повітряного теплообмінника на базі двофазного гравітаційного термосифону [8]. Конденсаційні зони теплової труби і повітряного теплообмінника через замкнутий контур циркуляції теплоносія підключені до випарника теплового насоса. (рис.1).

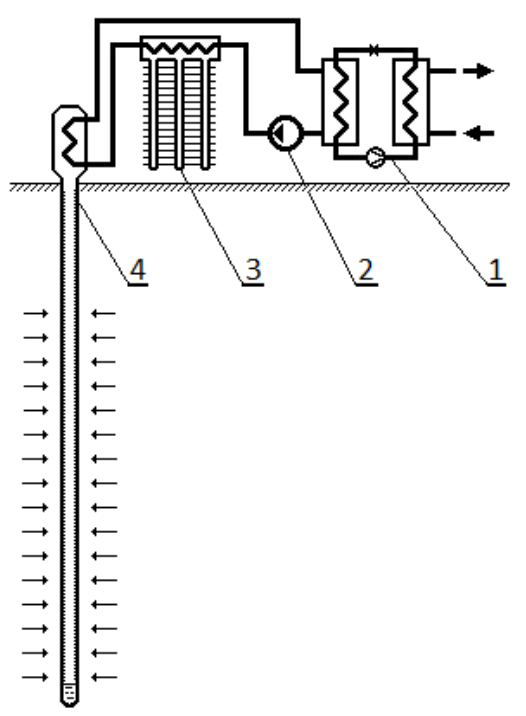

Рис. 1. Принципова схема системи теплонасосного теплопостачання з двома джерелами низькопотенційної теплоти: 1 - тепловий насос; 2 - цииркуляційний насос низькопотенційного теплоносія; 3 - повітряний теплообмінник; 4 - трунтовий теплообмінник.

Fig. 1. Schematic diagram of the heat pump heat supply system with two sources of low-potential heat: 1 - heat pump; 2 - circulation pump for low-grade heat carrier; 3 -air heat exchanger; 4 -ground heat exchanger.

Використання гравітаційних термосифонів дозволяє спростити управління системою вилучення тепла i максимально ефективно використовувати температурний потенціал обох джерел низькопотенційної теплоти. У процесі роботи термосифонного теплообмінного апарату легкокиплячий агент кипить в випарній зоні і відбирає теплоту від грунту або повітря. Пара, яка утворюється при кипінні агенту, надходить в конденсаційну зону, і конденсується віддаючи теплоту циркулюючому теплоносію, а рідкий агент стікає назад в випарну зону. Специфіка роботи конденсаційно-випарного гравітаційного термосифона полягає в тому, що він передає теплоту тільки в тому випадку, коли температура конденсаційної зони (теплоносія) нижче, ніж температура випарної зони (грунту, повітря). Внаслідок цього циркулюючий теплоносій автоматично відбирає теплоту від того джерела 
низькопотенційної теплоти, температура якого $\epsilon$ вищею.

При розрахунку енергетичних показників комбінованої системи теплопостачання нами були використані емпіричні формули для обчислення COP теплових насосів «повітря-вода» i «грунтвода», які отримані шляхом усереднення графіків залежності СОР від різниці температур $\Delta \mathrm{T}$ між конденсатором і випарником для більш ніж 100 комерційних моделей побутових теплових насосів потужністю до 20 кВт [9].

Залежність для розрахунку СОР теплового насоса «повітря-вода» [9]:

$$
\begin{gathered}
C O P_{\Pi-в}=6,81-0,121 \cdot \Delta T+0,00063 \cdot \Delta T^{2}, \\
\text { для } 15 \leq \Delta T \leq 60
\end{gathered}
$$

Залежність для розрахунку СОР теплового насоса «грунт-вода» [9]:

$$
\begin{gathered}
C O P_{\Gamma-B}=8,77-0,15 \cdot \Delta T+0,000734 \cdot \Delta T^{2}, \\
\text { для } 20 \leq \Delta T \leq 60 \\
\Delta T=T_{\kappa}-T_{6},
\end{gathered}
$$

де $T_{\kappa}-$ температура конденсатора, $\left({ }^{\circ} \mathrm{C}\right) ; T_{6}-$ температура випарника, $\left({ }^{\circ} \mathrm{C}\right)$.

При однакових температурних режимах роботи тепловий насос «грунт-вода» має більш високі значення СОР в порівнянні 3 тепловим насосом «повітря-вода». Це обумовлено тим, що об'ємна теплоємність повітря набагато менша, ніж у води, i на переміщення повітря через теплообмінник витрачається більше електроенергії в розрахунку на одиницю теплопродуктивності.

Як приклад, порівняємо сумарну річну теплопродуктивність повітряного і геотермального теплового насоса при роботі для забезпечення опалення та гарячого водопостачання в кліматичних умовах м. Києва. У розрахунках температуру нагрівання води в тепловому насосі приймаємо не нижче $55^{\circ} \mathrm{C}$, що відповідає гігієнічним вимогам до забезпечення безпеки систем гарячого водопостачання. Температуру грунтового масиву вважаємо постійною протягом року i рівній $10{ }^{\circ} \mathrm{C}$. Значення температур атмосферного повітря та тривалість періодів 3 температурою повітря різних градацій приймаємо згідно $з$ даними [11], (рис. 2).

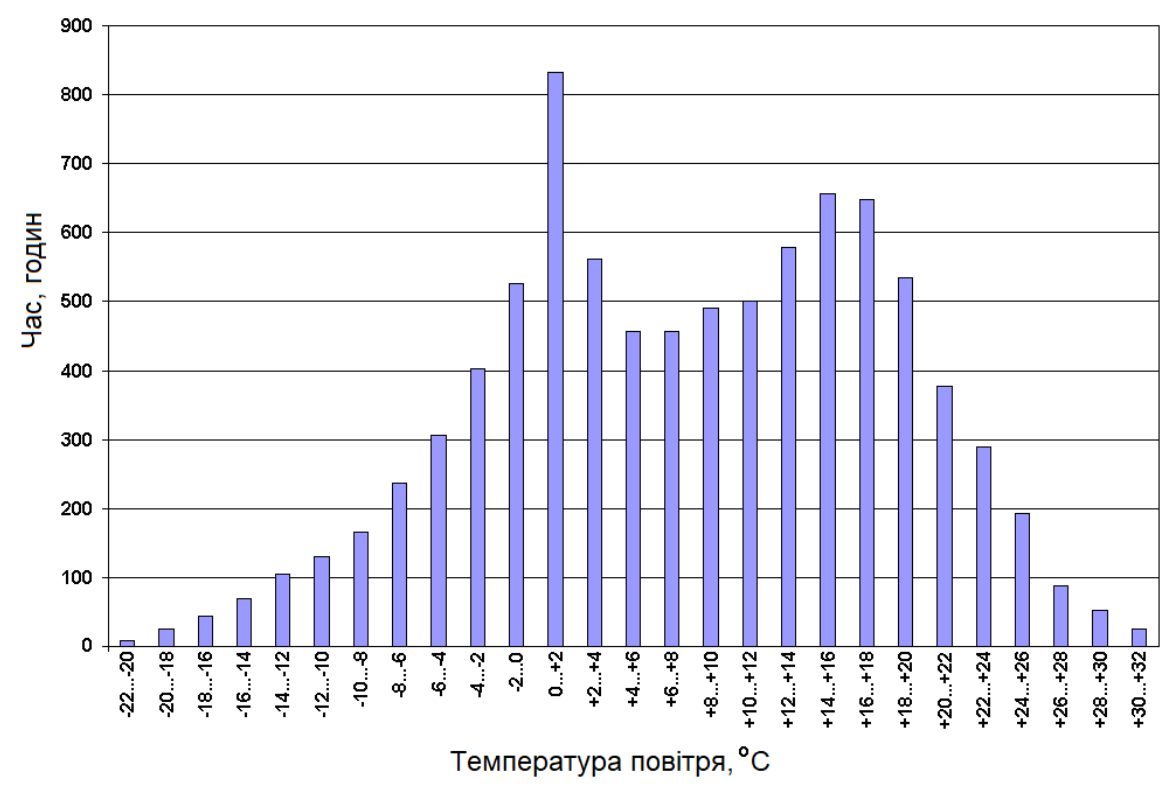

Рис. 2. Середня тривалість температури повітря різних градацій в м. Кисві.

Fig. 2. Average duration of air temperature of various gradations in Kiev.

Кількість теплової енергії, яка виробляється повітряним тепловим насосом при зазначених на гістограмі температурах повітря, розраховувалося 3 урахуванням тривалості даної температури i відповідного цій температурі значення коефіцієнта перетворення СОР, яке обчислювалося за залежностями (2), (3). Для порівняння ефективності теплонасосних систем в однакові періоди часу визначалася теплопродуктивність геотермального теплового насоса в тих же температурно-часових інтервалах. 
Теплопродуктивність повітряного теплового насоса залежить від температури повітря і за час стояння заданої температури повітря складає:

$$
\begin{aligned}
& Q_{\Pi-B}^{i}=N_{e л} \cdot\left[6,81-0,121 \cdot \Delta T_{i}+\right. \\
& \left.\quad+0,00063 \cdot \Delta T_{i}^{2}\right] \cdot \tau_{i}, \kappa B m \cdot г о \partial,
\end{aligned},
$$

де $N_{\text {eл }}$ - споживана тепловим насосом електрична потужність, $\tau_{i}-$ час стояння заданої температури повітря.

Різниця між температурами теплоносія i повітря складає:

$$
\Delta T_{i}=T_{\text {нагр }}-T_{\text {пов }}^{i},
$$

де $T_{\text {нагр }}-$ температура нагріву теплоносія в тепловому насосі $\left({ }^{\circ} \mathrm{C}\right), T_{n o в}^{i}-$ задана температура повітря, $\left({ }^{\circ} \mathrm{C}\right)$;
Теплопродуктивність геотермального теплового насоса за той же час дорівнює:

$$
\begin{aligned}
& Q_{\Gamma-B}^{i}=N_{e л} \cdot[8,77-0,15 \cdot \Delta T+ \\
& \left.+0,000734 \cdot \Delta T^{2}\right] \cdot \tau_{i}, \kappa B m \cdot г о \partial .
\end{aligned},
$$

Різниця між температурами теплоносія i грунту дорівнює:

$$
\Delta T=T_{\text {нагр }}-T_{\text {гp }},
$$

де $T_{\text {нагр. }}$ - температура нагріву теплоносія в тепловому насосі $\left({ }^{\circ} \mathrm{C}\right), \quad T_{2 p}$. $\quad$ температура грунту, $\left({ }^{\circ} \mathrm{C}\right)$.

В обох випадках споживана електрична потужність прийнята рівною 1 кВт. Отримані величини теплопродуктивності геотермального i повітряного теплового насоса при їх цілорічній роботі наведені на рис. 3 .

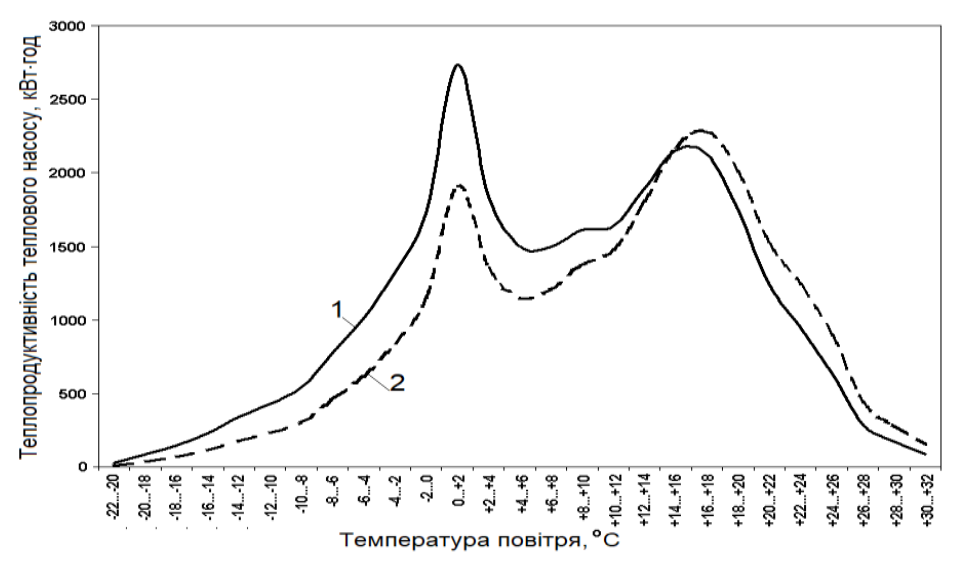

Рис. 3. Вплив тривалості температур повітря різних градацій на теплопродуктивність теплового насоса протягом року: 1 - геотермальний тепловий насос; 2 - повітряний тепловий насос.

Fig. 3. Influence of the duration of air temperatures of various gradations on the heat output of the heat pump throughout the year: 1 - geothermal heat pump; 2 - air source heat pump.

Як видно з графіків, більшу частину року, починаючи 3 мінімальних температур атмосферного повітря $-22 \ldots-20^{\circ} \mathrm{C}$ і до досягнення температур $+14 \ldots+16^{\circ} \mathrm{C}$, більш ефективно працює тепловий насос «грунт-вода». Тривалість цього періоду становить 6300 годин або 0,7 року. При цьому максимальна різниця в кількості виробленої теплової енергії порівнюваними теплонасосними системами доводиться на часовий період 3 температурою навколишнього середовища $0 . . .+2^{\circ} \mathrm{C}$.

Відповідно, період більш ефективної роботи повітряного теплового насоса в порівнянні 3 геотермальним припадає на теплу пору року, коли температура атмосферного повітря перевищує $+15^{\circ} \mathrm{C}$ (рис. 3). Влітку у Києві повітря може прогріватися до $32^{\circ} \mathrm{C}$, але найбільш тривалим за часом $\epsilon$ період 3 температурами повітря $17-18^{\circ} \mathrm{C}$ (рис. 2). Загальна теплопродуктивність повітряного теплового насоса в теплу пору, яка становить менше третини року (2540 годин), складає майже половину річної теплопродуктивності. Середньомісячні значення коефіцієнту перетворення геотермального теплового насоса на протязі всього року має практичне постійне значення. Температура низькопотенційного теплоносія, якщо глибина свердловини становить більше 10 метрів, постійна. Для геотермічних умов Києва вона становить $8-12^{\circ} \mathrm{C}$. Середньомісячні значення коефіцієнту перетворення геотермального і повітряного теплового насоса наведено на рисунку 4. 


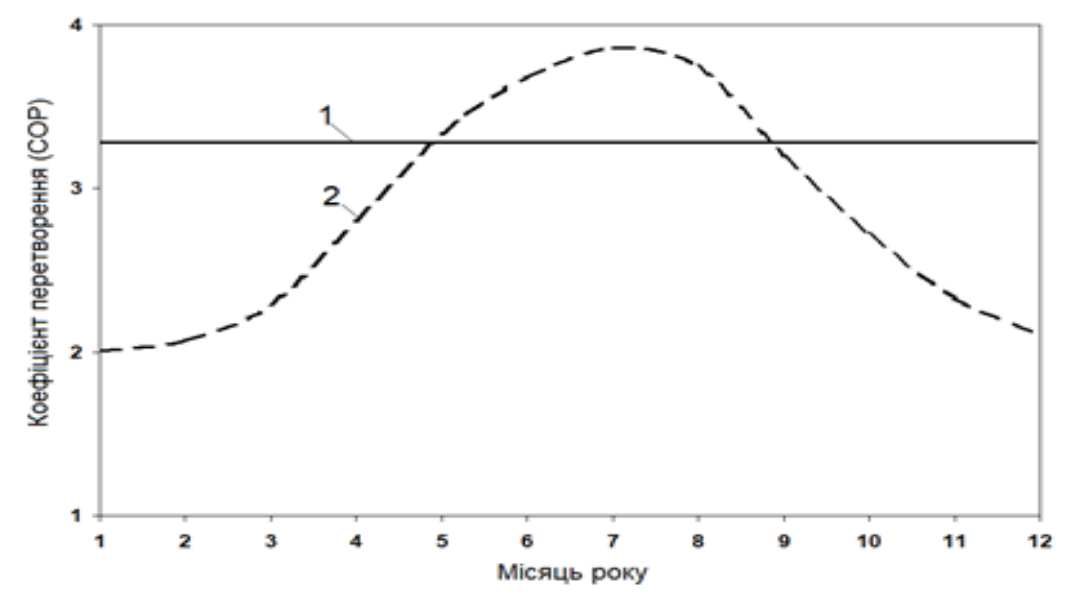

Рис. 4. Середньомісячні значення коефіціснту перетворення геотермального теплового насосу і повітряного теплового насосу: 1 - геотермальний тепловий насос; 2 - повітряний тепловий насос.

Fig. 4. Average monthly values of the conversion factor of geothermal heat pump and air source heat pump: 1 - geothermal heat pump; 2 - air source heat pump.

У зв'язку 3 цим має сенс визначити ефективність комбінованого використання теплового потенціалу довкілля i верхніх шарів Землі для роботи установок теплонасосного теплопостачання. В таблиці 2 наведено розрахункові дані питомої теплопродуктивності (кВт·год виробленої теплової енергії на 1 кВт споживаної електроенергіï) геотермального і повітряного теплового насосу при їх автономної i комбінованої роботі протягом року в кліматичних умовах міста Києва. Результати розрахунку показують, що комбіноване використання низькопотенційної теплоти атмосферного повітря і грунту дозволяе при однаковому електроспоживанні в 1,2 рази збільшити річну теплопродуктивність в порівнянні 3 повітряним тепловим насосом 2.

Таблиця 2. Енергетичні показники автономної і комбінованої роботи повітряного теплового насосу $\mathbf{i}$ геотермального теплового насосу.

Table 2. Energy indicators of autonomous and combined operation of air source heat pump and geothermal heat pump.

\begin{tabular}{|l|c|c|c|c|}
\hline $\begin{array}{c}\text { теплонасосної } \\
\text { системи }\end{array}$ & $\begin{array}{c}\text { Вироблення } \\
\text { теплової енергії за } \\
\text { рік, кВт·год }\end{array}$ & $\begin{array}{c}\text { Вироблення } \\
\text { теплової енергії за } \\
\text { опалювальний } \\
\text { період, кВт·год }\end{array}$ & $\begin{array}{c}\text { Вироблення теплової } \\
\text { енергї̈ за } \\
\text { неопалювальний } \\
\text { період, кВт·год }\end{array}$ & $\begin{array}{c}\text { Середній СОР за } \\
\text { рік }\end{array}$ \\
\hline повітряна & 25290 & 9630 & 15660 & 2,9 \\
\hline геотермальна & 28750 & 14200 & 14550 & 3,3 \\
\hline комбінована & 30350 & 14200 & 16150 & 3,5 \\
\hline
\end{tabular}

Висновки. На теперішній час в системах теплонасосного теплопостачання найбільш широке практичне застосування отримали теплонасосні установки типу «повітря-вода» і «грунт-вода». Використання кожного 3 цих джерел низькопотенційної теплоти має свої переваги і недоліки. Перевагою повітря, як теплоносія, є те, що повітряні теплові насоси можуть працювати практично повсюди і не вимагають облаштування низькотемпературного контуру. Однак, через значні коливання температури зовнішнього повітря протягом року, ці системи характеризуються змінними енергетичними характеристиками, які мають тенденцію до зниження в найхолодніші періоди, коли потреба в теплі максимальна. На відміну від повітря грунт, як джерело низькопотенційної теплоти, відрізняється постійністю температури протягом усього року, однак, слід зауважити, що грунт $\epsilon$ кращим джерелом теплоти тільки протягом тієї частини року, коли температура грунту перевищує температуру атмосферного повітря. В іншу пору 
року енергетично більш ефективним $\epsilon$ використання теплоти атмосферного повітря. Перспективним способом підвищення ефективності теплового насоса при річному циклі його роботи (опалення взимку i гаряче водопостачання влітку) $\epsilon$ комбіноване використання низькопотенційної теплоти грунту та повітря. Теплонасосна система $з$ двома джерелами енергії забезпечує високу теплопродуктивність теплового насоса протягом всього року і має більш високий показник енергетичної ефективності у порівнянні з традиційними рішеннями.

1. Директива Європейського Парламенту та Ради 2009/28/СС від 23 квітня 2009 року. Про заохочення до використання енергії, виробленої з відновлюваних джерел тощо. Офіційний вісник європейського союзу 5.6.2009. L 140/16 -L140/62.

2. Морозов Ю.П. Добыча геотермальных ресурсов и аккумулирование теплоты в подземных горизонтах. Монография. Киев. Наукова думка. 2017. 197с.

3. Басок Б., Дубовской C. Методологические особенности оценки располагаемой мощности тепловых насосов в Украине. Насосы и оборудование. 2017. № 3(104). C. $42-44$.

4. Мінімальне допустиме значення середнього розрахункового сезонного коефіцієнту корисної дії. Державний комітет статистики України. [Електронний pecypc]. URL: http://ukrstat.gov.ua.

5. The heat pump stock of $13.3 \mathrm{~m}(12 \%)$ units in 2019 contributed. URL: http://www.stats.ehpa.org/hp_sales/countr у_cards. (дата звернення 25.10.2020).

6. Васильев Г.П., Горнов В.Ф., Колесова М.В. Исследование оценки эффективности комбинированного использования тепла грунта и атмосферного воздуха в теплонасосных системах теплохладоснабжения. Энергобезопасность и энергосбережение. 2014. № 1(55). C. 20-24.

7. Hou G., Taherian H. Performance analysis of a hybrid ground source heat pump system integrated with liquid dry cooler. Applied Thermal Engineering. 2019. Vol. 159.113830 p.

https://doi.org/10.1016/j.applthermaleng.2019.113830.

8. Морозов Ю.П., Чалаєв Д.М., Величко В.В. Патент на винахід № 125076. Україна. МПК F28D 15/00, F28D 15/02. Гравітаційна теплова труба. Заявл. 14.12.2017. Опубл. 25.04.2018. Бюл. № 8 .

9. Staffell I., Brett D., Brandonc N., Hawkes A. A review of domestic heat pumps. Energy Environ. Sci. 2012. № 5. Pp. 92919306. https://doi.org/10.1039/C2EE22653G.

10. ДСТУ-Н Б В.1.1-27:2010 Будівельна кліматологія. Введ. 01.11.2011. К. Укрархбудінформ. 2011. 123 с.

11. Строительная климатология. Справочное пособие к СНиП 23-01-99. М. Стройиздат. 1990. 86 с.

\section{REFERENCES}

1. Dyrektyva Yevropeyskoho Parlamentu ta Rady 2009/28/YES vid 23 kvitnya 2009 roku. Pro zaokhochennya do vykorystannya enerhiyi, vyroblenoyi $\mathrm{z}$ vidnovlyuvanykh dzherel toshcho. [Directive 2009/28/EC of the European Parliament and of the Council of 23 April 2009 on the promotion of energy produced from renewable sources, etc.] Official Journal of the European Union 5.6.2009. L140/16-L140/62. [in Ukrainian].

2. Morozov Yu.P. Dobycha heotermalnykh resursov y akkumulyrovanye teploty $\mathrm{v}$ podzemnykh horyzontakh. [Extraction of geothermal resources and accumulation of heat in underground horizons]. Monograph. Kiev. Naukova dumka. 2017. 197 p. [in Russian].

3. Basok B., Dubovskoy S. Metodolohycheskye osobennosty otsenky raspolahaemoy moshchnosty teplovykh nasosov v Ukrayne. Nasosy y oborudovanye. [Methodological features of assessing the available capacity of heat pumps in Ukraine]. Pumps and equipment. 2017. No. 3(104). Pp. 42-44. [in Russian].

4. Minimalne dopustyme znachennya serednoho rozrakhunkovoho sezonnoho koefitsiyentu korysnoyi diyi. [The minimum permissible value of the average rorachunkovy seasonal factor of the coriander]. State Committee of Statistics of Ukraine. [Electronic resource]. URL: http://ukrstat.gov.ua. Name from the screen. [in English].

5. The heat pump stock of $13.3 \mathrm{~m}(12 \%)$ units in 2019 contributed. URL: http://www.stats.ehpa.org/hp_sales/countr y_cards. (Applying date: 25.10.2020). [in English].

6. Vasiliev G.P., Gornov V.F., Kolesova M.V. Yssledovanye otsenky éffektyvnosty kombynyrovannoho yspol'zovanyya tepla hrunta $\mathrm{y}$ atmosfernoho vozdukha $\mathrm{v}$ teplonasosnykh systemakh teplokhladosnabzhenyya. [Study of evaluation of efficiency of combined use of soil heat and atmospheric air in heat pump systems of heat and cold supply]. Energy security and energy saving. 2014. No. 1(55). Pp. 20-24. [in Russian].

7. Hou G., Taherian H. Performance analysis of a hybrid ground source heat pump system integrated with liquid dry cooler. Applied Thermal Engineering. 2019. Vol. 159.113830 p.

https://doi.org/10.1016/j.applthermaleng.2019.113830. [in English].

8. Morozov YP, Chalaev DM, Velichko VV Patent na vynakhid № 125076. [Patent for invention № 125076]. Ukraine. IPC F28D 15/00, F28D 15/02. Gravitational heat pipe. Application 12/14/2017 Publ. 04/25/2018 Bull. No. 8. [in Ukrainian].

9. Staffell I., Brett D., Brandonc N., Hawkes A. A review of domestic heat pumps. Energy Environ. Sci. 2012. № 5. Pp. 92919306. https://doi.org/10.1039/C2EE22653G. [in English].

10. DSTU-N B V.1.1-27:2010 Budivel'na klimatolohiya. [DSTU-N B V.1.1-27: 2010 Budivelna klimatology]. Entering 01.11.2011. K. Ukrrhbudinform. 2011. 123 p. [in Ukrainian].

11. Stroytelnaya klymatolohyya. [Construction climatology]. Reference manual to SNiP 23-01-99. M. Stroyizdat. 1990. 86 p. [in Russian]. 